\title{
A fuzzy- rough set approach to determine weights in maintenance quality function deployment
}

\author{
Davy George Valavi ${ }^{a^{*}}$ and V.R. Pramod ${ }^{\mathrm{b}}$
}

${ }^{a}$ Research Scholar, Mechanical Engineering, Karpagam University, Coimbatore, India

${ }^{b}$ Associate Professor, Department of Mechanical Engineering, NSS college of Engineeing, Palakkad, India

\author{
C H R O N I C L E

\begin{tabular}{l}
\hline Article history: \\
Received February 25, 2016 \\
Received in revised format: \\
March 28, 2016 \\
Accepted August 12, 2016 \\
Available online \\
August 122016 \\
\hline Keywords: \\
Maintenance Quality Function \\
Deployment \\
Fuzzy set \\
Rough set
\end{tabular}
\begin{abstract}
A B S T R A C T
Maintenance Qualitn Function Deployment (MQFD) is a methodology for improving the quality and effectiveness of maintenance services in a manufacturing organization. One major part of it is House of Quality (HoQ). HoQ translates the experts' voice into technical requirements for the improvement of maintenance quality. These data are generally vague in nature. Fuzzy numbers are generally used to represent vague data in HoQ. Since some parameters are predefined in fuzzy approach, the experts' opinion may not be truly reflected in the HoQ analysis. In this work, a rough set - fuzzy approach, is proposed for MQFD to overcome this drawback. The objective of this model is to prioritize the technical requirements effectively with the proper reflection of customers/experts' perceptions in the output. An illustrative example is presented to explain this approach.
\end{abstract}

\section{Introduction}

In the competitive business environment, the survival depends on the organization's ability to meet the uncertainties, successfully. Hence, the organizations tend to use new technologies and systems to improve the quality of products and services. In this scenario, it is necessary to make the machines and the facilities more reliable and efficient. Most companies try to achieve uninterrupted production, highe quality of product, lower production cost, flexibility of system and operational safety. These objectives can be met to a great extent by adopting a proper maintenance system. The discipline of maintenance quality engineering, came forth in the mid twentieth century, has fast developed by embracing new methods and techniques (Decker, 1996; Chan et al., 2005). The Total Productive Maintenance (TPM) framework was evolved in 1970s in Japan. The mission of TPM is the elimination of all losses and effective utilization of all resources with the active involvement of employees at all levels. The TPM has proven successful in achieving a higher degree of maintenance quality (Mekone et al., 2001; Sherwin, 2000). Total quality management (TQM) was developed based on the pioneering works

* Corresponding author.

E-mail address: davygeorge@gmail.com (D. G. Valavi)

(C) 2017 Growing Science Ltd. All rights reserved.

doi: $10.5267 /$ j.ds1.2016.8.002 
of Deming and Juran in 1980's. The ultimate aim of TQM is defect elimination. Researchers started linking the two methodologies to achieve the highest quality and efficiency of the maintenance system. Duffuaa and Ben Daya (1995) explained that the seven quality tools can be used to improve maintenance quality. Quality Function Deployment (QFD), a tool adopted in TQM to translate customer Requirements (CR) into Technical Requirements (TR), has been found successful in many industries and applications (Carnevalli \& Miguel, 2008). Several works have been progressing in the direction of connecting TPM with TQM to include customer's voice in maintenance quality improvement plan. Al-Najjar and Alsyouf (2000) presented a model called Total Quality Maintenance (TQMain). Lazreg (2010) developed Maintenance Excellence Model (MEM) by linking maintenance with QFD and six sigma. Pramod et al. (2006) proposed a model called Maintenance Quality Function Deployment (MQFD) to have a synergy gain in maintenance quality by linking TPM with QFD. Evaluation of the relative importance or weightages of CRs and TRs is a critical step in MQFD process. Hence the MQFD model, validated in different practical scenarios, was modified by including AHP and Fuzzy AHP to determine the relative importance of CRs (Pramod et al., 2006, 2007a, 2007b, 2008).

Most of the decision making in the real world take place in situations where the vagueness is associated with the information. In such scenario, fuzzy numbers, instead of crisp data, can be used to represent the vague or imprecise data. Chen and Weng (2006), Ko and Chen (2014), Mechefske and Wang, (2003) and Verma et al. (2007) proposed fuzzy models that consider the correlation between TRs. However, the fuzzy theory requires some additional information such as membership grade and predefined boundary intervals. The outcomes are influenced by those parameters. In MQFD, the customers are usually experienced personnel in the organization and they are usually less in number. So a careful analysis of the customers' response is required to determine the relative importance of CRs and TRs. The rough set theory, proposed by Pawlak (1982), does not require any predefined parameters. The rough numbers and rough boundary interval, proposed by Zhai et al. (2008, 2010), can provide more insight into the customer voice. The rough boundary intervals are determined directly from the data and not predefined by the analyst.

Many research works on HoQ are concentrated on the CRs, TRs, their interrelationships and the correlation between TRs. But in some applications like MQFD, there may be correlations between CRs also. So it is necessary to include both in the HoQ analysis. In this work, a methodology based on rough number and fuzzy approaches is proposed to analyze the House of Qualtiy (HoQ) data in MQFD. This model considers the correlations between CRs in addition to the correlation between TRs. The objective is to determine the relative importance of Customer Requirements CRsand TRs in MQFD more effectively. This paper is arranged as follows. MQFD, HoQ and rough set theory are illustrated in section 2, The proposed method is explained in section 3. Section 4 explains an illustrative example followed by Results and conclusions in the subsequent sections.

\section{Maintenance quality function deployment}

The major features of MQFD are described in this section. The MQFD framework is shown in Fig. 1. The customers' perceptions about the CRs are collected which are then used by the QFD team to develop HoQ. HoQ is a tool to translate customers' voice into technical requirements (TRs). The customers in MQFD are experts in the organization. The CRs and TRs are mainly maintenance or TPM related. The number of customers (experts), in the HoQ analysis of MQFD, is usually fewer in numbers compared to that in other domains. Since the customers (experts) are familiar with their functions, the variations in the customers' perception will be lesser. These technical requirements are submitted to the management for making strategic decisions. Researchers have emphasized that the strategic approach is essential for the success of QFD and TPM projects (Lu \& Kuei, 1995; Hunt \& Xavier, 2003). Tactical plans are formulated for implementation of these technical requirements. These Plans are then applied in the production system. The implementations have to be focussed on increasing the 
values of the maintenance quality performance measures such as Overall Equipment Efficiency (OEE), Mean Time Between Failures (MRBF), Mean Time To Repair (MTTR), Performance Quality (PQ),Availability and Mean Down Time (MDT).

The outputs are compared with the set targets to develop hook for the next cycle. The result of the implementation of MQFD will be the improvement in maintenance quality, enhancement in equipment life, improvement in OEE etc. The implementation of MQFD model is a continuous improvement process.

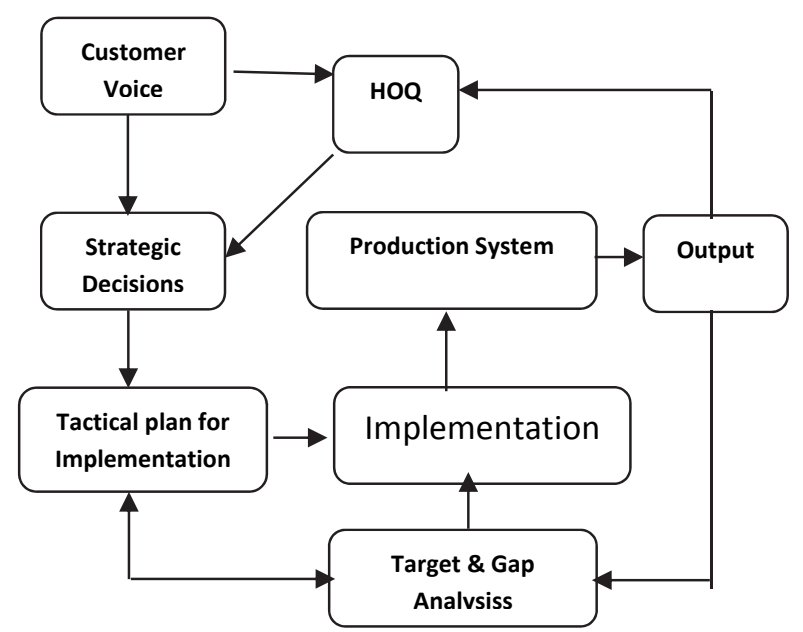

Fig. 1. MQFD framework

A unique feature of the MQFD model is that it does not necessitate extensive changes in the existing continuous improvement processes like TQM and TPM which may be practiced in the company. Thus, MQFD model enables the link between QFD and TPM.

\subsection{House of Quality}

One of the major elements in MQFD is HoQ. An HoQ contains matrices to represent the data on CRs, TRs, the relative importance of CRs, Relationship between CRs and TRs. In HoQ, a cell in the relationship matrix is assigned with value $R_{i j}$ which represents the degree of relationship between $C_{i}$ and $T R_{j} . A$ cell in the correlation matrix is assigned with the value $r_{i j}$ which denotes the degree of association between $\mathrm{TR}_{\mathrm{i}}$ and $\mathrm{TR}_{\mathrm{j}}$. A column matrix is for representing the relative importance of CRs. A cell in this matrix is assigned with value $\mathrm{W}_{\mathrm{i}}$ to represent the relative importance of $\mathrm{CR}_{\mathrm{i}}$. The matrices usually contain subjective information. The values may be represented by linguistic data such as 'high', ' medium', 'low' etc. Or it can be represented by numerals like 1,3, 5, 7, etc. to indicate the subjective information. The absolute importance rating of $\mathrm{TR}_{\mathrm{j}}$,

$$
A R_{j}=\sum_{i=1}^{m} \text { WiRij, } \quad \forall \mathrm{j}=1 \ldots . \mathrm{J}
$$

where $i, j$ are indices for $\mathrm{CR}$ and TR respectively, and $W_{i}$ is the relative importance of $\mathrm{CR}_{\mathrm{i}}$. The relative importance rating for $\mathrm{TR}_{\mathrm{j}}$,

$$
R R_{j}=\mathrm{ARj} / \sum_{j=1}^{n} A R j
$$

The TRs with higher relative importance can be selected for implementation. In HoQ, customer's perceptions, called as voice of customers(voc), about CRs and TRs are collected. Generally, these data are expressed in linguistic terms and are vague or imprecise. So researchers started using fuzzy numbers instead of crisp values in HoQ. Some of the works in this area include Khoo and Ho (1996) and Chan et al. (1999) in which symmetrical triangular fuzzy numbers(STFN) are used to analyze the vague information to determine the importance of CRs. Kahraman et al. (2006) used the fuzzy optimization technique to determine the importance of TRs. But in fuzzy approach, the fuzzy membership grade and boundary intervals are predetermined. So the result may not reflect the true perceptions of customers. Zhai et al. $(2008,2010)$ proposed a rough number approach to overcome this drawback. Most of the 
research work does not consider the correlation between CRs. But in some applications like MQFD, there may be a correlation between CRs. So it is necessary to include that also in the HoQ analysis. Based on rough number and fuzzy approaches, a methodology is proposed in this paper to analyze the HoQ data that include a correlation between CRs in addition to the correlation between TRs

\subsection{Rough Set Theory}

Rough set theory, like fuzzy theory, is an approach to make decisions when the information is imprecise or vague. The main advantage of this theory, introduced in 1980s by Pawlak (1982), is that it does not require additional information about data like probability in statistics, membership grade in fuzzy theory. In rough set theory, the imprecision or vagueness is expressed by a bounded region of sets. The topological operations, interior and closure, called as approximations can be used to explain rough sets. Two crisp sets are associated with every rough set, lower approximation set and upper approximation set. The lower approximation consists of all elements that certainly belong to it and the upper approximation consists of all elements that have a possibility to be included in the set. The boundary region, which is the difference between the upper and lower approximations, consists of all elements that cannot be classified to the set or its complement. Hence rough set has a non empty boundary region.

For computing the relative importance of CRs, the data collected from customers are presented in a tabular form, called as information table, with rows corresponding to customers (objects) and columns corresponding to CRs (attributes). The values in the cells are attribute values or the class values which objects assign to each attribute. The rough sets approximations are explained by Pawlak $(1982,1991)$

Consider that $U$ is the universe containing all objects in the universe. Let $\mathrm{R}=\left\{\mathrm{C}_{1}, \mathrm{C}_{2}, . . \mathrm{C}_{\mathrm{i}}, \ldots, \mathrm{C}_{\mathrm{n}}\right\}$ be the classes and if the classes are ordered in the ascending order, then for any class, $C_{i}$, the lower approximation, upper approximation and boundary region are defined by Eq.(3) to Eq.(5) respectively

$$
\begin{aligned}
& C_{i=}^{l} \cup\left\{X \in U / R(X) \leq C_{i}\right. \\
& C_{i=}^{u} \cup\left\{X \in U / R(X) \geq C_{i}\right. \\
& B R=\cup\left\{X \in U / R(X) \neq C_{i}\right.
\end{aligned}
$$

The lower approximation of $\mathrm{C}_{\mathrm{i}}$ contains all the objects that have attribute values less than or equals $\mathrm{C}_{\mathrm{i}}$ for a particular attribute and its approximation contains all the objects that have attribute values greater than or equals $C_{i}$ for that attribute. The band interval contains all the objects that have attribute values other than $C_{i}$ for that particular attribute. Zhai et al. $(2008,2010)$ introduced two concepts known as rough numbers and rough intervals which are illustrated below. A rough number $(\mathcal{R} \mathcal{N})$ can be attached to the class $\mathrm{C}_{\mathrm{i}}$ with the lower limit $\mathcal{L} C_{i}^{l}$ and the upper limit $\mathcal{L} C_{i}^{u}$.

$$
\begin{aligned}
& \mathcal{L} \mathrm{C}_{i=}^{l} \frac{1}{N^{L}} \Sigma R(X) \mid X \in \mathrm{C}_{i}^{l} \\
& \mathcal{L} \mathrm{C}_{i=}^{u} \frac{1}{N^{U}} \Sigma R(X) \mid X \in \mathrm{C}_{i}^{u}
\end{aligned}
$$

where $N^{L}$ and $N^{U}$ are the number of objects in the lower approximation and upper approximation respectively. The rough boundary interval and the rough number can be determined using Eq. (8) and Eq. (9), respectively

$$
\begin{aligned}
& \mathcal{R B}=\mathcal{L} \mathrm{C}_{i}^{u}-\mathcal{L} \mathrm{C}_{i}^{l} \\
& \mathcal{R \mathcal { N }}=\left[\mathcal{L} \mathrm{C}_{i}^{l}, \mathcal{L} \mathrm{C}_{i}^{u}\right]
\end{aligned}
$$

The basic operations on triangular fuzzy numbers (Ross. 2010, Yen and Langari,1998) are given below.

$$
\begin{aligned}
& \tilde{x}_{1} \oplus \tilde{x}_{2}=\left(x_{1}^{l}+x_{2}^{l}, x_{1}^{m}+x_{2}^{m}, x_{1}^{u}+x_{2}^{u}\right) \\
& \tilde{x}_{1} \otimes \tilde{x}_{2}=\left(x_{1}^{l} * x_{2}^{l}, x_{1}^{m} * x_{2}^{m}, x_{1}^{u} * x_{2}^{u}\right)
\end{aligned}
$$




$$
\begin{aligned}
-\tilde{x}_{1} & =\left(-x_{1}^{l},-x_{1}^{m},-x_{1}^{u}\right) \\
1 / \tilde{x}_{1} & =\left(1 / x_{1}^{u}, 1 / x_{1}^{m}, 1 / x_{1}^{l}\right)
\end{aligned}
$$

where $\cong$ denotes approximation, $\tilde{x}_{1}=\left(x_{1 l}, x_{1 m}, x_{1 u}\right)$ and $\tilde{x}_{2}=\left(x_{2 l}, x_{2 m}, x_{2 u}\right)$ represent two fuzzy triangular numbers with lower, modal and upper values. Zhai et al. (2008) extended these fuzzy operations to rough numbers. The rough number operations are mentioned below.

$$
\begin{aligned}
& x_{1} \oplus x_{2}=\left(x_{1}^{l}+x_{2}^{l},, x_{1}^{u}+x_{2}^{u}\right) \\
& x_{1} \otimes x_{2}=\left(x_{1}^{l} * x_{2}^{l}, x_{1}^{u} * x_{2}^{u}\right) \\
& -x_{1}=\left(-x_{1}^{l},-x_{1}^{u}\right) \\
& 1 / x_{1}=\left(1 / x_{1}^{u}, 1 / x_{1}^{l}\right)
\end{aligned}
$$

\section{Rough set-fuzzy model for MQFD}

In MQFD, one of the main elements is HoQ. The HoQ is a tool to translate the customer requirements into technical requirements. Since the objective of MQFD is to improve the efficiency and quality maintenance, the customers are experts mainly from production and maintenance departments of the firm. So the number of customers needed may be less than that of HoQs used in other domains. The customer requirements and technical requirements are mainly concerned with the maintenance and safety. The major steps involved in the model are explained below

\subsection{Step 1. Identification of Customer Requirements and Determination of Relative Importance}

The CRs are identified after a thorough analysis. Then the customers opinion about the importance of each CR can be collected and tabulated in an information table. The rows of the table represent customers (objects) and the columns represent CRs (attributes). A data in a cell represent the class value (attribute value) which a customer assigns to a particular customer requirement. Eq. (3) to Eq. (9) can be used to transform these data to rough numbers, $c_{e i}=\left[\mathrm{c}_{\mathrm{ei}}{ }^{\mathrm{L}}, \mathrm{c}_{\mathrm{ei}}{ }^{\mathrm{U}}\right]$, where $\mathrm{c}_{\mathrm{ei}}$ is the rough number of attribute value assigned by customer e to $\mathrm{CR}_{\mathrm{i}}$. These rough numbers are used to determine the absolute and relative importance of $\mathrm{CR}_{\mathrm{i}}$. The absolute importance of $\mathrm{CR}_{\mathrm{i}}$ and the normalized relative importance of $\mathrm{CR}_{\mathrm{i}}$, can be determined using Eq. (18) and Eq.(19) respectively.

$$
\begin{aligned}
& w_{i}^{A}=\left[w_{i}^{L A}, w_{i}^{U A}\right]=\left[\sum_{e=1}^{E} C_{\mathrm{ei}}\right] \\
& w_{i}=\left[w_{i}^{l}, w_{i}^{U}\right]=w_{i}^{A} /\left[\max \left\{w_{i}^{U A}\right\}\right]
\end{aligned}
$$

\subsection{Step 2 Determination of Normalized Interrelationship Values Between CRs and TRs}

This step consists of two stages. The first stage is Identification of influencing TRs, collection of data about the interrelationships and correlations and conversion of data to normalized rough numbers. The second stage is normalization of interrelationship values based on the correlations among CRs and among TRs.. The first stage can be carried out as follows. Collect the interrelations data of $\mathrm{CR}_{\mathrm{i}}$ and $\mathrm{TR}_{\mathrm{j}}$ from customers/ experts(e). These values are linguistic values. These values are converted to rough numbers, $R_{\mathrm{ije}}=\left[\mathrm{R}_{\mathrm{ije}}{ }^{\mathrm{L}}, \mathrm{R}_{\mathrm{ije}} \mathrm{U}\right]$, using Eq.(3) to Eq.(9). The average interrelations rough numbers are normalized to (0-1) range. Similarly collect the correlation data between CRs and between TRs from the experts which can be converted to rough numbers, $v_{\text {ige }}=\left[\mathrm{v}_{\text {ige }} \mathrm{L}^{\mathrm{L}}, \mathrm{v}_{\mathrm{ige}}^{\mathrm{U}}\right]$ and $\mathrm{r}_{j l e}=\left[\mathrm{r}_{\mathrm{jle}}^{\mathrm{L}}, \mathrm{r}_{\mathrm{jle}}^{\mathrm{U}}\right]$, using Eq.(3) to Eq.(9). vige is the rough number of correlation value between $C_{i}$ and $C R_{g}$ of expert e, where $\mathrm{i}, \mathrm{g}=(1, . . \mathrm{I})$ and $\mathrm{r}_{\mathrm{jle}}$ is the rough number of correlation value between $\mathrm{TR}_{\mathrm{j}}$ and $\mathrm{TR}_{1}$ of expert $\mathrm{e}$, where $\mathrm{j}$, $1=(1, \ldots, \mathrm{J})$. The average rough numbers of both the correlations are normalized to $(0-1)$ range.

The normalized rough number of average interrelation between $\mathrm{CR}_{\mathrm{i}}$ and $\mathrm{TR}_{\mathrm{j}}$,

$$
\mathrm{R}_{\mathrm{ij}}=\left[\sum_{e=1}^{E} R_{\mathrm{ij}} e^{L}, \sum_{e=1}^{E} R_{\mathrm{ij}} e^{u}\right] / \max \left\{\mathrm{R}_{\mathrm{ij}} e^{u}\right\}
$$


The normalized rough number of average correlation between $\mathrm{CR}_{\mathrm{i}}$ and $\mathrm{CR}_{\mathrm{g}}$,

$$
\mathrm{V}_{\mathrm{ig}}=\left[\sum_{e=1}^{E} V_{\mathrm{ig}} e^{L}, \sum_{e=1}^{E} V_{\mathrm{ig}} e^{u}\right] / \max \left\{\sum_{e=1}^{E} V_{\mathrm{ig}} e^{u}\right\}
$$

The normalized rough number of average correlation between $\mathrm{TR}_{\mathrm{j}}$ and $\mathrm{TR}_{\mathrm{l}}$,

$$
\mathrm{r}_{\mathrm{jl}}=\left[\sum_{e=1}^{E} r_{\mathrm{jle}}^{\mathrm{L}}, \sum_{e=1}^{E} r_{\mathrm{jle}}^{\mathrm{U}}\right] / \max \left\{\sum_{e=1}^{E} r_{\mathrm{jle}}^{\mathrm{U}}\right\}
$$

The second stage is the normalization of the interrelationship values, $\mathrm{R}_{\mathrm{ij}}$ considering the correlations between TRs and the correlation between CRs. Some researchers have done work on the normalization of interrelationship values between CRs and TRs. Chen and Weng (2006) proposed a fuzzy equation based on Wasserman (1993) to determine the normalized relationship between CRs and TRs considering the correlations between TRs. Ko and Chen (2014) formulated a more accurate fuzzy relationship equations. In this model, these formulae are applied to rough numbers and are defined by Eq.(23) and Eq.(24). In addition to the correlations between TRs, the correlations between CRs also are considered in this model. The normalization is carried out in two steps. First, the normalization is carried out to include the correlation between TRs. Then these values are normalized considering the correlations between CRs. The first stage normalized interrelationship values, $R_{i j}{ }^{\prime}=\left[R_{i j}{ }^{\circ}{ }^{2}, R_{i j}{ }^{\circ}\right]$, can be calculated using the $\mathrm{Eq}(23)$ to $\mathrm{Eq}(24 \mathrm{a})$.

$$
\begin{aligned}
& \left(R_{i j}^{\prime}\right)^{\mathrm{L}}=\sum_{\mathrm{l}=1}^{\mathrm{J}} \mathrm{R}_{\mathrm{il}}^{\mathrm{L}} \mathrm{r}_{\mathrm{lj}}^{\mathrm{L}} /\left(\sum_{\mathrm{l}=1}^{\mathrm{j}} \mathrm{R}_{\mathrm{il}}^{\mathrm{L}} \mathrm{r}_{\mathrm{lj}}^{\mathrm{L}}+\sum_{k=1, k \neq j}^{J} \sum_{\mathrm{l}=1}^{\mathrm{j}} \mathrm{R}_{\mathrm{il}}^{\mathrm{U}} \mathrm{r}_{\mathrm{lk}}^{\mathrm{U}}\right) \\
& \left(R_{i j}^{\prime}\right)^{\mathrm{L}}=\mathrm{R}_{\mathrm{il}}^{\mathrm{L}} \quad \text { If } \quad \sum_{k=1, k \neq j}^{J} \sum_{\mathrm{l}=1}^{\mathrm{j}} \mathrm{R}_{\mathrm{il}}^{\mathrm{U}} \mathrm{r}_{\mathrm{lk}}^{\mathrm{U}}=0 \\
& \left(R_{i j}^{\prime}\right)^{\mathrm{U}}=\left\{\sum_{\mathrm{l}=1}^{\mathrm{J}} \mathrm{R}_{\mathrm{il}}^{\mathrm{U}} \mathrm{r}_{\mathrm{lj}}^{\mathrm{U}} /\left(\sum_{\mathrm{l}=1}^{\mathrm{j}} \mathrm{R}_{\mathrm{il}}^{\mathrm{U}} \mathrm{r}_{\mathrm{lj}}^{\mathrm{U}}+\sum_{k=1, k \neq j}^{J} \sum_{\mathrm{l}=1}^{\mathrm{j}} \mathrm{R}_{\mathrm{il}}^{\mathrm{L}} \mathrm{r}_{\mathrm{lk}}^{\mathrm{L}}\right)\right. \\
& \left(R_{i j}^{\prime}\right)^{\mathrm{U}}=\mathrm{R}_{\mathrm{il}}^{\mathrm{L}} \quad \text { If } \quad \sum_{k=1, k \neq j}^{J} \sum_{\mathrm{l}=1}^{\mathrm{j}} \mathrm{R}_{\mathrm{il}}^{\mathrm{L}} \mathrm{r}_{\mathrm{lk}}^{\mathrm{L}}=0
\end{aligned}
$$

These normalized values are further normalized to include the correlation between CRs, to obtain the final normalized interrelationship values, $\mathrm{R}_{\mathrm{ij}}{ }^{\prime}=\left[\mathrm{R}_{\mathrm{ij}}{ }^{,{ }^{\prime}}, \mathrm{R}_{\mathrm{ij}}{ }^{\prime} \mathrm{U}\right]$, using the Eq.(25) and Eq (26).

$$
\begin{aligned}
& \left(R_{i j}^{\prime \prime}\right)^{\mathrm{L}}=\left\{\sum_{\mathrm{g}=1}^{\mathrm{I}} \mathrm{v}_{\mathrm{ig}}^{\mathrm{L}} \mathrm{R}_{\mathrm{gj}}^{\prime \mathrm{L}} /\left(\sum_{\mathrm{g}=1}^{\mathrm{I}} \mathrm{v}_{\mathrm{ig}}^{\mathrm{L}} \mathrm{R}_{\mathrm{g}}^{\prime \mathrm{L}}+\sum_{h=1, h \neq i}^{I} \sum_{\mathrm{g}=1}^{\mathrm{I}} \mathrm{v}_{\mathrm{ig}}^{\mathrm{U}} \mathrm{R}_{\mathrm{gh}}^{\prime \mathrm{U}}\right)\right. \\
& \left.\left(R_{i j}^{\prime \prime}\right)^{\mathrm{L}}=\mathrm{R}_{\mathrm{il}}^{\prime \mathrm{L}} \text { If } \sum_{h=1, h \neq i}^{I} \sum_{\mathrm{g}=1}^{\mathrm{I}} \mathrm{v}_{\mathrm{ig}}^{\mathrm{U}} \mathrm{R}_{\mathrm{gh}}^{\prime \mathrm{U}}\right)=0 \\
& \left(R_{i j}^{\prime \prime}\right)^{\mathrm{U}}=\left\{\sum_{\mathrm{g}=1}^{\mathrm{I}} \mathrm{v}_{\mathrm{ig}}^{\mathrm{U}} \mathrm{R}_{\mathrm{gj}}^{\prime \mathrm{U}} /\left(\sum_{\mathrm{g}=1}^{\mathrm{I}} \mathrm{v}_{\mathrm{ig}}^{\mathrm{U}} \mathrm{R}_{\mathrm{gj}}^{\prime \mathrm{U}}+\sum_{h=1, h \neq i}^{I} \sum_{\mathrm{g}=1}^{\mathrm{I}} \mathrm{v}_{\mathrm{ig}}^{\mathrm{L}} \mathrm{R}_{\mathrm{gh}}^{\prime \mathrm{L}}\right)\right. \\
& \left.\left(R_{i j}^{\prime \prime}\right)^{\mathrm{U}}=\mathrm{R}_{\mathrm{il}}^{\prime \mathrm{U}} \text { If } \sum_{h=1, h \neq i}^{I} \sum_{\mathrm{g}=1}^{\mathrm{I}} \mathrm{v}_{\mathrm{ig}}^{\mathrm{L}} \mathrm{R}_{\mathrm{gh}}^{\prime \mathrm{L}}\right)=0
\end{aligned}
$$

\subsection{Step 3. Determination of Final Importance Rating of TRS}

The final importance ratings can be calculated using the formula

Absolute importance rating and relative importance rating of $\mathrm{TR}_{\mathrm{j}}$ can be calculated using Eq. (27) and Eq. (28), respectively.

$$
\begin{aligned}
& \mathrm{AR}_{\mathrm{j}}=\left[\sum_{i=1}^{I} W_{\mathrm{I}} \mathrm{R}_{\mathrm{ij}}{ }^{\prime} \mathrm{IR}_{\mathrm{i}}, \sum_{i=1}^{I} W_{\mathrm{i}} \mathrm{R}_{\mathrm{ij}}{ }^{\prime} \mathrm{IR}_{\mathrm{i}}\right] \\
& \mathrm{RR}_{\mathrm{j}}=\left[\sum_{i=1}^{I} W_{\mathrm{I}} \mathrm{R}_{\mathrm{ij}}{ }^{\prime}{ }^{\mathrm{L}} \mathrm{IR}_{\mathrm{i}}, \sum_{i=1}^{I} W_{\mathrm{i}} \mathrm{R}_{\mathrm{ij}}{ }^{,} \mathrm{IR}_{\mathrm{i}}\right] / \sum_{i=1}^{I} W_{\mathrm{i}} \mathrm{R}_{\mathrm{ij}}{ }^{\prime} \mathrm{IR}_{\mathrm{i}}
\end{aligned}
$$

\subsection{Step 4. Ranking of TRs}

The final step is ranking of TRs. The following rules can be applied for ranking of any two rough numbers $\mathrm{X}_{1}=\left[\mathrm{x}_{1}{ }^{\mathrm{L}}, \mathrm{x}_{1}{ }^{\mathrm{U}}\right]$ and $\mathrm{X}_{2}=\left[\mathrm{X}_{2}^{\mathrm{L},} \mathrm{x}_{2}^{\mathrm{U}}\right]$.

i) If one rough interval is not strictly bounded, i.e., if $\left(\mathrm{x}_{1} \mathrm{U}_{>} \mathrm{x}_{2}{ }^{\mathrm{U}}\right.$ and $\left.\mathrm{x}_{1}{ }^{\mathrm{L}}>=\mathrm{x}_{2}{ }^{\mathrm{L}}\right)$ or if $\left(\mathrm{x}_{1} \mathrm{U}_{>}=\mathrm{x}_{2}{ }^{\mathrm{U}}\right.$ and $\mathrm{x}_{1}{ }^{\mathrm{L}}>\mathrm{x}_{2}{ }^{\mathrm{L}}$ ), then the rank of $\mathrm{X}_{1}>\mathrm{X}_{2}$. 
ii) If $\mathrm{x}_{1}{ }^{\mathrm{U}}=\mathrm{x}_{2}{ }^{\mathrm{U}}$ and $\mathrm{x}_{1}{ }^{\mathrm{L}}=\mathrm{x}_{2}{ }^{\mathrm{L}}$, then the rank of $\mathrm{X}_{1}=\mathrm{X}_{2}$

iii) If $\left(\mathrm{x}_{1}{ }^{\mathrm{U}}>\mathrm{x}_{2}{ }^{\mathrm{U}}\right.$ and $\left.\mathrm{x}_{1}{ }^{\mathrm{L}}<\mathrm{x}_{2}{ }^{\mathrm{L}}\right)$ or if $\left(\mathrm{x}_{2}{ }^{\mathrm{U}}>\mathrm{x}_{1}{ }^{\mathrm{U}}\right.$ and $\left.\mathrm{x}_{2}{ }^{\mathrm{L}}<\mathrm{x}_{1}{ }^{\mathrm{L}}\right)$, then decision can make a criteria to rank it. In this work, the mean is is used for ranking. If $m_{1}$ is the mean of $X_{1}$ and $m_{2}$ is the mean of $X_{2}$, Then the following criteria can be used to run the numbers. If $\left(\mathrm{x}_{1}{ }^{\mathrm{U}}>\mathrm{x}_{2}{ }^{\mathrm{U}}\right.$ and $\left.\mathrm{x}_{1}{ }^{\mathrm{L}}<\mathrm{x}_{2}{ }^{\mathrm{L}}\right)$ and if $\mathrm{m}_{1=<} \mathrm{m}_{2}$, then the rank of $\mathrm{X}_{1}<\mathrm{X}_{2}$ and if $\mathrm{m}_{1}>\mathrm{m}_{2}$, then the rank of $\mathrm{X}_{1}>\mathrm{X}_{2}$. Similar criteria can be applied if $\left(\mathrm{x}_{1} \mathrm{U}_{<\mathrm{x}_{2}}^{\mathrm{U}}\right.$ and $\left.\mathrm{x}_{1}{ }^{\mathrm{L}}>\mathrm{x}_{2}{ }^{\mathrm{L}}\right)$.

\section{Illustraive example}

To illustrate the above concept, an example pertaining to a job order shop is explained here. This shop is a part of an organization in India specialized in installing and maintaining hydroelectric power generating stations. It is a medium size plant and their main objectives are to complete the projects in specified time and to maintain the quality of works. They have business across India.So the company wants to improve the OEE to meet that objective. Here a sample of five people working in the supervisory management cadre of the manufacturing and maintenance departments is considered as customers (experts). A small subset of CRs consisting of five requirements and five corresponding TRs is presented here for the purpose of illustration. The CRs are (1) Eliminate breakdowns $\left(\mathrm{CR}_{1}\right),(2)$ Eliminate quality defects $\left(\mathrm{CR}_{2}\right)$, (3) Empower operators to look after their own equipment $\left(\mathrm{CR}_{3}\right)$, (4) improve the expertise of operator and maintenance personnel $\left(\mathrm{CR}_{4}\right)$ and (5) Achieve and sustain zero accidents $\left(\mathrm{CR}_{5}\right)$. The TRs considered are (1) Set day to day action plan for maintenance(TR $\left.)_{1}\right),(2)$ Proper spare parts management $\left(\mathrm{TR}_{2}\right)$, (3) Preventive maintenance plan( $\left.\mathrm{TR}_{3}\right),(4)$ Training( $\left.\mathrm{TR}_{4}\right)$ and (5) Make machines and workplace safe $\left(\mathrm{TR}_{5}\right)$. The data pertaining to the interrelationships, correlations and improvement ratios are collected from experts. The data are presented in the following tables.

The data in the Table 1 show the experts opinion about the relative importance CRs, The crisp value, the rough numbers and fuzzy numbers are shown. This table contains additional information such as company's actual performance of each $\mathrm{CR}\left(\mathrm{Ap} \mathrm{p}_{\mathrm{i}}\right)$, company's target performance $\left(\mathrm{TP}_{\mathrm{i}}\right)$ and the improvement ratio, $\mathrm{IR}_{\mathrm{i}}=\mathrm{TP}_{\mathrm{i}} / \mathrm{Ap}_{\mathrm{i}}$. The actual performance and target performance are on $1-5$ scale with 1 as the lowest value and 5 as the highest value. This information is collected from the group as a whole and individual opinion is not considered. So only crisp data are considered. The lower and upper limits are calculated using Eq. (6) and Eq. (7) respectively. Consider the case of the opinion of expert $\left(\mathrm{e}_{2}\right)$ to $\mathrm{CR}_{1}$. The crisp value is 8 . The number of attribute values less than or equal to 8 for $\mathrm{CR}_{1}$ is 2 .

Using the Eq.(6), the lower approximation of 8 is $(8+8) / 2=8.0$. The number of attribute values greater than or equal to 8 is 5 .

The upper approximation of 8 is $(9+8+8+9+9) / 5=8.6$ and the rough number is [8.0 8.6].

The average value for $\mathrm{CR}_{1}$ is $([8.69 .0]+[8.0$ 8.6] $+[8.08 .6]+[8.69 .0]+[8.69 .0]) / 5=[8.448 .84]$.

The max upper approximation of $\mathrm{CR}_{\mathrm{i}}$ \} $=8.96$ (for $\mathrm{CR}_{2}$ ).

The normalized rough number of weightage for $\mathrm{CR}_{1}$ is [8.44 8.84] $/ 8.96=[.93 .99]$

For the purpose of comparison, the crisp and fuzzy values also are shown in Table 1.

The Table 2 and Table 3 represent the normalized correlation matrix between CRs and betweenTRs respectively. The data about the correlations are collected in the $1-5$ scale with 1 as lowest correlation and 5 as highest correlation. If there is no correlation, the cell is left blank (or value 0 can be assigned). Obviously, the data for $\mathrm{CR}_{\mathrm{ig}}=5$ if $\mathrm{I}=\mathrm{g}$ and $\mathrm{CR}_{\mathrm{ig}}=\mathrm{CR}_{\mathrm{gi}}$. Similarly for $\mathrm{TR}_{\mathrm{jl}}=5$ if $\mathrm{j}=1$ and $\mathrm{TR}_{\mathrm{jl}}=\mathrm{TR}_{\mathrm{lj}}$. The average rough numbers are entered in the respective cells of the corresponding matrix. Each cell is divided by the highest upper approximation value in the respective matrix to obtain the normalized correlation matrices(Eq.(21) and Eq.(22)). These values are represented by $\left[\mathrm{v}_{\mathrm{ig}}\right]$ and $\left[\mathrm{r}_{\mathrm{j}}\right]$ respectively. 


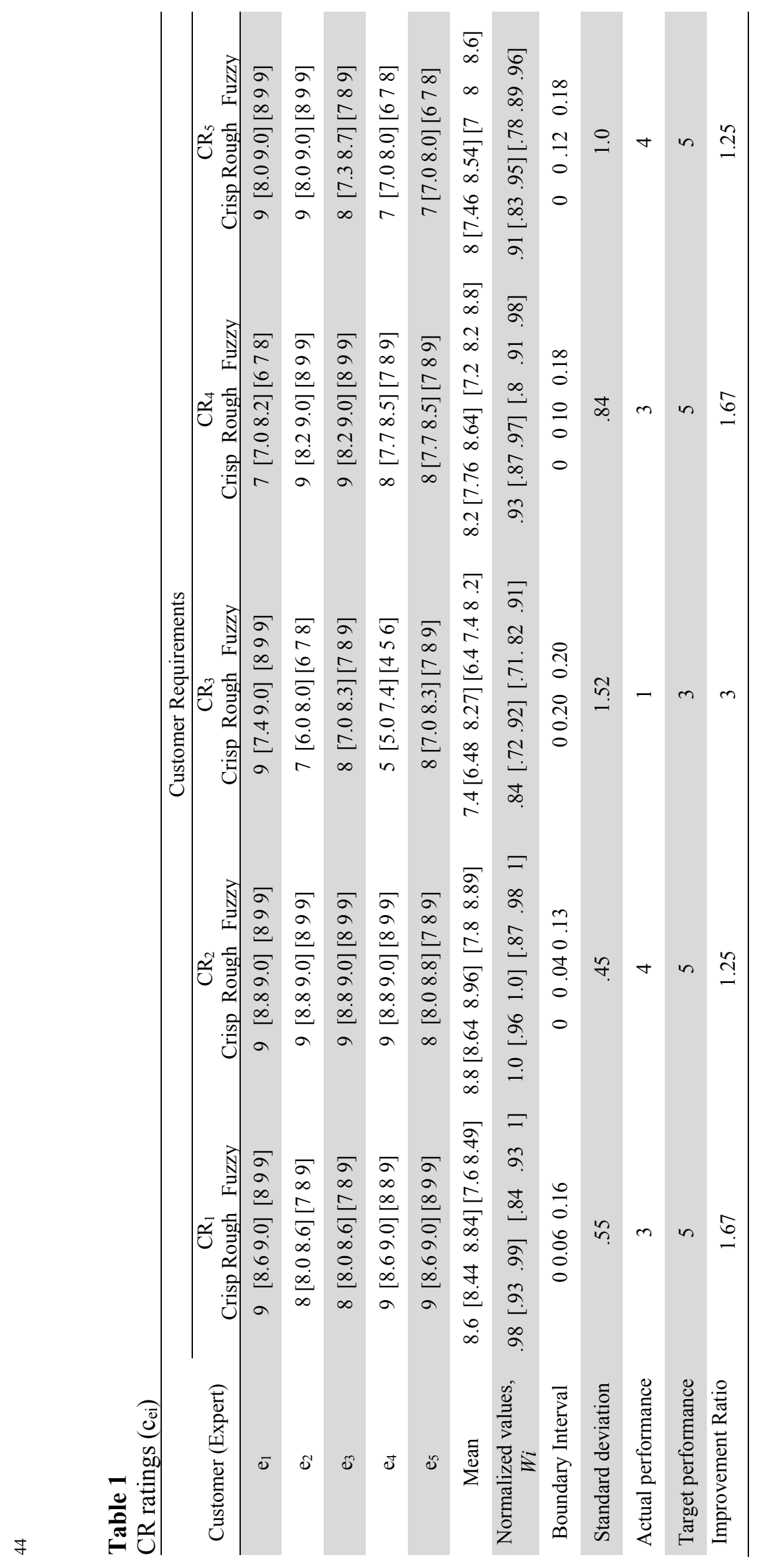


Table 2

CR correlation values $\left(\mathrm{V}_{\mathrm{ig}}\right)$

\begin{tabular}{cccccc}
\hline Customer & \multicolumn{5}{c}{ Customer Requirements } \\
\cline { 2 - 6 } Requirements & $\mathrm{CR}_{1}$ & $\mathrm{CR}_{2}$ & $\mathrm{CR}_{3}$ & $\mathrm{CR}_{4}$ & $\mathrm{CR}_{5}$ \\
\hline $\mathrm{CR}_{1}$ & {$[1.01 .0]$} & --- & {$[.63 .81]$} & {$[.67 .85]$} & --- \\
$\mathrm{CR}_{2}$ & -- & {$[1.01 .0]$} & --- & {$[.81 .95]$} & --- \\
$\mathrm{CR}_{3}$ & {$[.63 .81]$} & --- & {$[1.01 .0]$} & {$[.47 .57]$} & {$[.63 .73]$} \\
$\mathrm{CR}_{4}$ & {$[.67 .85]$} & {$[.81 .95]$} & {$[.47 .57]$} & {$[1.01 .0]$} & {$[.47 .57]$} \\
$\mathrm{CR}_{5}$ & --- & --- & {$[.63 .73]$} & {$[.47 .57]$} & {$[1.01 .0]$} \\
\hline
\end{tabular}

Table 3

TR correlation values $\left(\mathrm{r}_{\mathrm{j} l}\right)$

\begin{tabular}{cccccc}
\hline Technical & \multicolumn{5}{c}{ Technical Requirements } \\
\cline { 2 - 6 } Requirements & $\mathrm{TR}_{1}$ & $\mathrm{TR}_{2}$ & $\mathrm{TR}_{3}$ & $\mathrm{TR}_{4}$ & $\mathrm{TR}_{5}$ \\
\hline $\mathrm{TR}_{1}$ & {$[1.01 .0]$} & -- & {$[.83 .93]$} & --- & {$[.5 .67]$} \\
$\mathrm{TR}_{2}$ & -- & {$[1.01 .0]$} & {$[.53 .59]$} & --- & --- \\
$\mathrm{TR}_{3}$ & {$[.83 .93]$} & {$[.53 .59]$} & {$[1.01 .0]$} & {$[.41 .45]$} & {$[.41 .45]$} \\
$\mathrm{TR}_{4}$ & --- & --- & {$[.41 .45]$} & {$[1.01 .0]$} & {$[.83 .93]$} \\
$\mathrm{TR}_{5}$ & {$[.5 .67]$} & --- & {$[.41 .45]$} & {$[.83 .93]$} & {$[1.01 .0]$} \\
\hline
\end{tabular}

Table 4

CR-TR interrelations values and the normalized interrelation values

\begin{tabular}{|c|c|c|c|c|c|}
\hline \multirow[b]{2}{*}{ CRs } & \multicolumn{5}{|c|}{ Technical Requirements } \\
\hline & $\begin{array}{lrl}\left.R_{i j}\right] & \mathrm{TR}_{1} & \\
& {\left[R_{i j}{ }^{\prime \prime}\right]} & {\left[R_{i j}{ }^{\prime}\right]} \\
\end{array}$ & $\begin{array}{lrl} & \mathrm{TR}_{2} & \\
& & {\left[\mathrm{R}_{\mathrm{ij}}{ }^{\prime}\right]} \\
& {\left[\mathrm{R}_{\mathrm{ij}}{ }^{\prime \prime}\right]} & \\
\end{array}$ & $\begin{array}{lll} & \mathrm{TR}_{3} & \\
& & {\left[\mathrm{R}_{\mathrm{ij}}{ }^{\prime}\right]} \\
& {\left[\mathrm{R}_{\mathrm{ij}}{ }^{\prime \prime}\right]} & \\
\end{array}$ & $\begin{array}{lll}\left.\mathrm{R}_{\mathrm{ij}}\right] & \mathrm{TR}_{4} & \\
& {\left[\mathrm{R}_{\mathrm{ij}}{ }^{\prime \prime}\right]} & {\left[\mathrm{R}_{\mathrm{ij}}{ }^{\prime}\right]} \\
\end{array}$ & $\begin{array}{lrr} & \mathrm{TR}_{5} & \\
& & {\left[\mathrm{R}_{\mathrm{ij}}{ }^{\prime}\right]} \\
& {\left[\mathrm{R}_{\mathrm{ij}}{ }^{\prime}\right]} & \\
\end{array}$ \\
\hline $\mathrm{CR}_{1}$ & 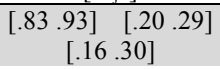 & $\begin{array}{c}{[.27 .37][.08 .12]} \\
{[.12 .29]}\end{array}$ & 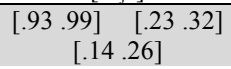 & $\begin{array}{c}.63 .73] \quad[.15 .20] \\
{[.12 .29]}\end{array}$ & $\begin{array}{c}{[.43 .53]} \\
{[.14} \\
{[.24]}\end{array}$ \\
\hline $\mathrm{CR}_{2}$ & $\begin{array}{c}{[.22 .30] \quad[.10 .15]} \\
{[.08 .17]}\end{array}$ & $\begin{array}{c}{[.20 .20]\left[\begin{array}{l}.06 \\
{[.08]}\end{array}\right]} \\
{[.10 .23]}\end{array}$ & $\begin{array}{c}{\left[\begin{array}{ll}.21 & .27\end{array}\right]\left[\begin{array}{ll}.21 & .32\end{array}\right]} \\
{[.12 .19]}\end{array}$ & $\begin{array}{c}{[.97 .95] \quad[.24 .30]} \\
{[.12 .20]}\end{array}$ & 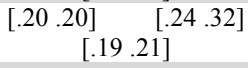 \\
\hline $\mathrm{CR}_{3}$ & 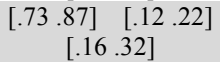 & $\begin{array}{c}{[.20 .20][.03 .06]} \\
{[.15 .38]}\end{array}$ & $\begin{array}{c}{[.31 .47] \quad[.29 .39]} \\
{[.17 .31]}\end{array}$ & 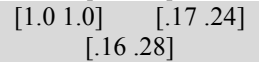 & 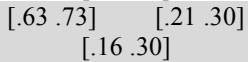 \\
\hline $\mathrm{CR}_{4}$ & 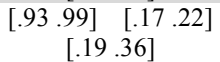 & $\begin{array}{c}{[.83 .93][, 12.16]} \\
{[.18 .38]}\end{array}$ & 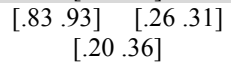 & $\begin{array}{c}{\left[\begin{array}{ll}1.0 & 1.0\end{array}\right]\left[\begin{array}{cc}.16 & .18\end{array}\right]} \\
{[.22 .36]}\end{array}$ & $\left.\begin{array}{c}{[.32 .33]} \\
{[.21} \\
{[.37]}\end{array}\right]$ \\
\hline $\mathrm{CR}_{5}$ & $\begin{array}{c}{[.55 .67]\left[\begin{array}{ll}.19 & .25\end{array}\right]} \\
{[.10 .24]}\end{array}$ & $\begin{array}{c}{[.20 .20][.07 .09]} \\
{[.14 .19]}\end{array}$ & 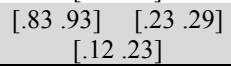 & 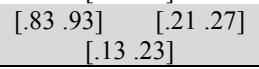 & $\begin{array}{c}{\left[\begin{array}{ll}1.0 & 1.0\end{array}\right]\left[\begin{array}{ll}.18 & .24\end{array}\right]} \\
{[.11 .22]}\end{array}$ \\
\hline
\end{tabular}

The interrelations values are shown in Table 4. The data are collected using the $1-5$ scale with 1 being the lowest interrelation and 5 being the highest. If there is no interrelation, the cell is left blank (or value 0 ). The average rough numbers in each cell is divided by the highest upper approximation of average rough number in the matrix to obtain the initial normalized values in $(0-1)$ range. The Eq (20) is used to obtain the values $\left[R_{i j}\right]$. The values $\left[R_{i j}\right]$ from Table $4,\left[\mathrm{v}_{\mathrm{ig}}\right]$ from Table 2 , [ $\left.\mathrm{r}_{\mathrm{j} i}\right]$ from Table 3 and the Eq.(23) to Eq.(26) are used to obtain the values $\left[\mathrm{R}_{\mathrm{ij}}{ }^{\prime}\right]$ and $\left[\mathrm{R}_{\mathrm{ij}}{ }^{\prime}\right]$ of Table 4.

For example, to get the values of $\left[\mathrm{R}_{\mathrm{ij}}{ }^{\prime}\right]$ and $\left[\mathrm{R}_{\mathrm{ij}}{ }^{\prime}\right]$, the following operations are performed.

$\sum_{l=1}^{J} R_{11} \mathrm{r}_{11}=[.83 .93]\left[\begin{array}{ll}1 & 1\end{array}\right]+[.27 .37][00]+\left[\begin{array}{ll}.93 & .99\end{array}\right][.83 .93]+\left[\begin{array}{ll}.63 & .73\end{array}\right]\left[\begin{array}{l}0 \\ 0\end{array}\right]+\left[\begin{array}{ll}.63 & .53\end{array}\right][.5 .67]=\left[\begin{array}{ll}1.85 & 2.30\end{array}\right]$

$\sum_{l=1}^{J} R_{11} \mathrm{r}_{12}=[.83 .93][00]+[.27 .37]\left[\begin{array}{ll}1 & 1\end{array}\right]+[.93 .99][.53 .59]+\left[\begin{array}{ll}.63 & .73\end{array}\right]\left[\begin{array}{ll}0 & 0]\end{array}\right]+[.63 .53][00]=[.76 .95]$

The other values are $\sum_{l=1}^{J} R 11 \mathrm{r}_{13}=\left[\begin{array}{ll}2.19 & 2.64\end{array}\right], \sum_{l=1}^{J} R 11 \mathrm{r}_{14}=\left[\begin{array}{lll}1.37 & 1.67\end{array}\right]$ and

$\sum_{l=1}^{J} R 11 \mathbf{r}_{15}=\left[\begin{array}{ll}1.75 & 2.22\end{array}\right]$.

$\mathrm{R}_{11}{ }^{\mathrm{L}} \mathrm{L}=1.85 /(1.85+(.95+2.64+1.67+2.22))=.20$

$\mathrm{R}_{11}{ }^{\prime} \mathrm{U}=2.30 /(2.30+(.76+2.19+1.37+1.75))=.29$

Similarly the second stage normalization can be carried out to get the values $\left[\mathrm{R}_{\mathrm{ij}}{ }^{\prime}\right]$

The absolute importance rating of $\mathrm{TR}_{\mathrm{j}}$ is calculated using the $\mathrm{Eq}(27)$. Consider the case of $\mathrm{TR}_{1} . A R_{l}=$ $\mathrm{W}_{1} \mathrm{R}_{11}$ "IR $\mathrm{IR}_{1}+\mathrm{W}_{2} \mathrm{R}_{21}$ "IR $\mathrm{IR}_{2}+\mathrm{W}_{3} \mathrm{R}_{31}$ "IR $\mathrm{IR}_{3}+\mathrm{W}_{4} \mathrm{R}_{41}$ "IR $4+\mathrm{W}_{5} \mathrm{R}_{51}$ "IR

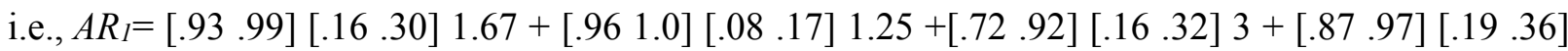
$1.67+[7.468 .54][.10 .24] 1.25=[.25 .50]$

The absolute ratings of TRs are [. 25. 50], [.14 .36], [.30 .71], [.17, .47] and [.14.29] respectively. The 
relative importances, calculated using $\mathrm{Eq}(28)$, are [. 35.70], [.20 .51], [.42 1.0], [.24 .66] and [. 20 .41] respectively. The final step is to rank the TRs. The guidelines mentioned in section 4.4 are used to rank the TRs. The ranking of TRs is $\mathrm{TR}_{3}>\mathrm{TR}_{1}>\mathrm{TR}_{4}>\mathrm{TR}_{2}>\mathrm{TR}_{5}$.

\section{Results and discussions}

The ranking of the CRs and TRs are obtained using the rough set -fuzzy approach. The ranking of CRs is $\mathrm{CR} 2>\mathrm{CR} 1>\mathrm{CR} 4>\mathrm{CR} 5>\mathrm{CR} 3$ and that of $\mathrm{TRs}$ is $\mathrm{TR}_{3}>\mathrm{TR}_{1}>\mathrm{TR}_{4}>\mathrm{TR}_{2}>\mathrm{TR}_{5}$. For the comparison purpose, the rough, fuzzy and crisp values are shown in Tqable1. STFN and alpha value of zero are used in fuzzy analysis. There may not be any change in the ranking of CRs between the approaches. One reason is that the symmetrical triangular membership function used is for fuzzy analysis. However, the ranking may change if some other membership functions and alpha values are used. But more important is the differences in the boundary interval between the two approaches. It can be seen that the rough boundary interval depends on the variability of the data collected from the experts. That is, the variability in the experts' perception about attributes(CRs). Higher the variation, wider the interval. Whereas, the fuzzy boundary interval depends on the fuzzy membership function, boundary interval and the alpha values which all are predefined.That may have an impact on the ranking of attributes. This means the rough set analysis gives more insight into customer perception than fuzzy analysis. The Figure 3 shows the relationship of rough interval and fuzzy interval with standard deviation of the data.

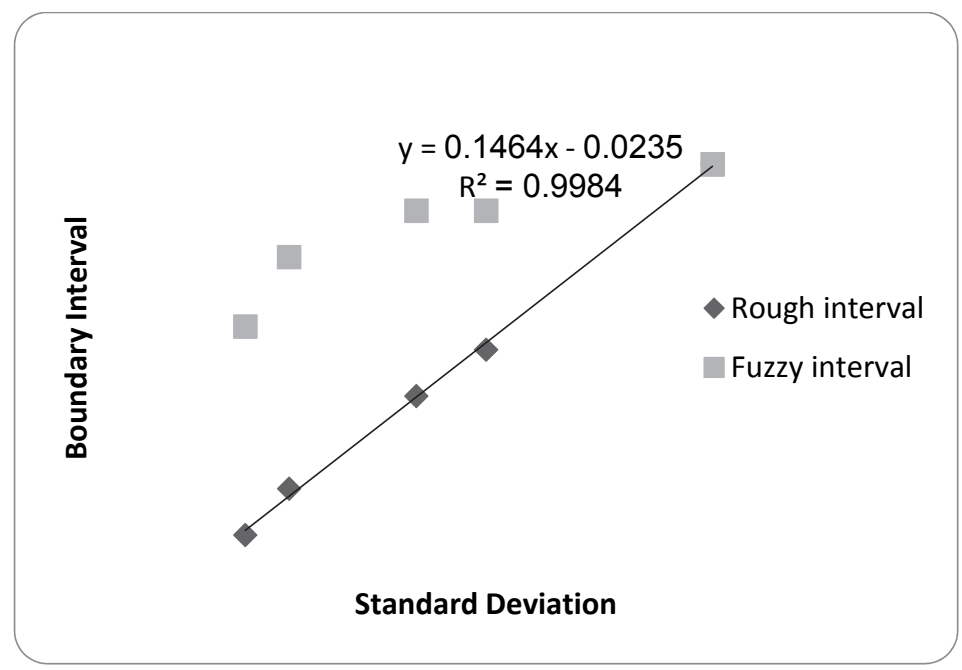

Fig. 3. Boundary interval v/s sample standard deviation

In the case of rough interval, there is almost a linear relationship. However, there is no evidence of such relationship in the case of fuzzy interval. The rough interval is zero if all experts give the same perception about an attribute.The rough interval is maximum when all experts give a different perception about an attribute. So the rough analysis is best suited in situations when there is less variation in the perception of customers. In MQFD analysis, the customers/experts are experienced people who have a thorough expertise in their work environment, the variation in their perceptions may be lesser compared to other situations. Further, the number of parameters required for rough set analysis is only two, lower and upper limits. Whereas, in the case of fuzzy analysis, four parameters are required, lower and upper limits, membership grade value and membership function. So the computation is less complex in rough set analysis. Hence the rough - fuzzy approach can be a superior method in MQFD.

\section{Conclusion}

Proper prioritization of CRs and TRs are crucial in MQFD. The main data which are used to determine those priorities are customer/experts' perceptions. These are generally vague and imprecise.Fuzzy numbers has been widely used to represent vague and imprecise data.One drawback of fuzzy approach 
is that the boundary intervals and membership grade values are predefined by the analysts. This may lead to the improper analysis of customers' perceptions about attributes. This drawback can overcome by using rough sets in which the rough boundary intervals are determined by from the collected data witout predefining any parameters.. So the rough numbers may give better insight into the customer perceptions. Hence, in this work, a rough- fuzzy approach is adopted in MQFD. However, the rough boundary interval depends on the variability of customer perception about an attribute. So this approach is better suited for situations in which there is less variability in customer perceptions. The objective of MQFD is to improve the quality of maintenance service. Therefore the CRs and TRs are mainly maintenance related and the customers/ experts chosen will be well experienced maintenance \& production personnel from the organization. So there may be less chance for large variations in their perceptions about CRs and TRs. Further, The computation is less complex in rough set analysis as less number of parameters are required. So this methodology provides a better approach to MQFD to prioritize TRs.

\section{References}

Al-Najjar, B., \& Alsyouf, I. (2000). Improving effectiveness of manufacturing systems using total quality maintenance. Integrated Manufacturing Systems, 11(4), 267-276.

Carnevalli, J. A., \& Miguel, P. C. (2008). Review, analysis and classification of the literature on QFDTypes of research, difficulties and benefits. International Journal of Production Economics, 114(2), 737-754.

Chan, F. T. S., Lau, H. C. W., Ip, R. W. L., Chan, H. K., \& Kong, S. (2005). Implementation of total productive maintenance: a case study. International Journal of Production Economics, 95(1), 7194.

Chan, L. K., Kao, H. P., \& Wu, M. L. (1999). Rating the importance of customer needs in quality function deployment by fuzzy and entropy methods. International Journal of Production Research, 37(11), 2499-2518.

Chen, L. H., \& Weng, M. C. (2006). An evaluation approach to engineering design in QFD processes using fuzzy goal programming models. European Journal of Operational Research, 172(1), 230248.

Dekker, R. (1996). Applications of maintenance optimization models: a review and analysis. Reliability Engineering \& System Safety, 51(3), 229-240.

Duffuaa, S. O., \& Ben-Daya, M. (1995). Improving maintenance quality using SPC tools. Journal of Quality in Maintenance Engineering, 1(2), 25-33.

Hunt, R. A., \& Xavier, F. B. (2003). The leading edge in strategic QFD.International Journal of Quality \& Reliability Management, 20(1), 56-73.

Kahraman, C., Ertay, T., \& Büyüközkan, G. (2006). A fuzzy optimization model for QFD planning process using analytic network approach. European Journal of Operational Research, 171(2), 390411.

Khoo, L. P., \& Ho, N. C. (1996). Framework of a fuzzy quality function deployment system. International Journal of Production Research, 34(2), 299-311.

Ko, W. C., \& Chen, L. H. (2014). An approach of new product planning using quality function deployment and fuzzy linear programming model. International Journal of Production Research, 52(6), 1728-1743.

Kwong, C. K., \& Bai, H. (2002). A fuzzy AHP approach to the determination of importance weights of customer requirements in quality function deployment.Journal of Intelligent Manufacturing, 13(5), 367-377.

Lazreg, M. (2010). Integrated model linking Maintenance Excellence, Six Sigma and QFD for process progressive improvement. Quality Management and Six Sigma, 67-87.

Lu, M. H., \& Kuei, C. H. (1995). Strategic marketing planning: a quality function deployment approach. International Journal of Quality \& Reliability Management, 12(6), 85-96.

McKone, K. E., Schroeder, R. G., \& Cua, K. O. (2001). The impact of total productive maintenance 
practices on manufacturing performance. Journal of Operations Management, 19(1), 39-58.

Mechefske, C. K., \& Wang, Z. (2003). Using fuzzy linguistics to select optimum maintenance and condition monitoring strategies. Mechanical Systems and Signal Processing, 17(2), 305-316.

Pawlak, Z. (1982). Rough sets. International Journal of Computer \& Information Sciences, 11(5), 341 356.

Pawlak, Z. (1991). Rough sets: Theoretical aspects of reasoning about data (Vol. 9). Springer.

Pramod, V. R., Devadasan, S. R., \& Jagathy Raj, V. P. (2006). Customer voice adoption for maintenance quality improvement through MQFD and its receptivity analysis. International Journal of Management Practice, 2(2), 83-108.

Pramod, V. R., Devadasan, S. R., \& Jagathy Raj, V. P. (2007). Receptivity analysis of TPM among internal customers. International Journal of Technology, Policy and Management, 7(1), 75-88.

Pramod, V. R., Sampath, K., Devadasan, S. R., \& Jagathy Raj, V. P. (2007). Multicriteria decision making in maintenance quality function deployment through the analytical hierarchy process. International Journal of Industrial and Systems Engineering, 2(4), 454-478.

Pramod, V. R., Devadasan, S. R., Jagathy Raj, V. P., \& Murugesh, R. (2008). MQFD and its receptivity analysis of an Indian electronic switch manufacturing company. International Journal of Management Practice, 3(1), 82-95.

Ross, T. J. (2009). Fuzzy logic with engineering applications. John Wiley \& Sons.

Sherwin, D. (2000). A review of overall models for maintenance management.Journal of Quality in Maintenance Engineering, 6(3), 138-164.

Verma, A. K., Srividya, A., \& Prabhu Gaonkar, R. S. (2007). Technical Note: Fuzzy Set Solutions for Optimal Maintenance Strategy Selection. Opsearch,44(3), 261.

Wasserman, G. S. (1993). On how to prioritize design requirements during the QFD planning process. IIE transactions, 25(3), 59-65.

Yen, J., \& Langari, R. (1998). Fuzzy logic: intelligence, control, and information. Prentice-Hall, Inc

Zhai, L. Y., Khoo, L. P., \& Zhong, Z. W. (2008). A rough set enhanced fuzzy approach to quality function deployment. The International Journal of Advanced Manufacturing Technology, 37(5-6), 613-624.

Zhai, L. Y., Khoo, L. P., \& Zhong, Z. W. (2010). Towards a QFD-based expert system: A novel extension of the fuzzy QFD methodology using rough set theory. Expert Systems with Applications, $37(12), 8888-8896$.

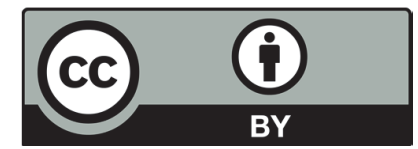

(C) 2016 by the authors; licensee Growing Science, Canada. This is an open access article distributed under the terms and conditions of the Creative Commons Attribution (CC-BY) license (http://creativecommons.org/licenses/by/4.0/). 